\title{
A GEOGRAPHICAL STUDY OF HUMAN RESOURCES DEVELOPMENT IN AHMEDNAGAR DISTRICT, MAHARASHTRA, INDIA
}

\author{
Shejul Meena Eknath ${ }^{1}$ \\ ${ }^{1}$ Asst. Teacher, \\ Good Shepherd School, \\ A/P-Kadit, Tal- Shirampur Dist- Ahmednagar \\ Tupe B. $\mathbf{K}^{3}$. \\ ${ }^{3}$ Bharatratna Dr. Babasaheb Ambedkar Jr. Col. \\ Bhagwatipur, \\ Kolhar, \\ Tal. Rahata, Dist. A. Nagar, \\ M.S. India.
}

\author{
Kadam Vaishali $\mathbf{C}^{2}$ \\ ${ }^{2} \mathrm{At} / \mathrm{p}$ Loni,
} Tal. Rahata, Dist. A. Nagar, M.S. India

\author{
Gulave S.D ${ }^{4}$ \\ ${ }^{4,}$ Assistant Professor, \\ Padmashri Vikhe Patil College of Arts Science \\ $\&$ Commerce, \\ Pravaranagar Maharashtra, India. \\ Department of Geography UG and PG, \\ Affiliated Savitribai Phule Pune University \\ Pune.
}

\author{
Gadekar Deepak J 5 \\ ${ }^{5}$ Assistant Professor, \\ Padmashri Vikhe Patil College of Arts Science \& Commerce, \\ Pravaranagar Maharashtra, India. \\ Department of Geography UG and PG, \\ Affiliated Savitribai Phule Pune University \\ Pune.
}

\begin{abstract}
Human resources is importance for economic development of any nation. Economic development of a region is depending on the development of human and natural resources because of Man he develops with his knowledge, skilled and good health. (Gadekar Deepak $J$ 2015) the economic status of any country depends on the domestic and foreign tourist as tourist are the resources of any nation. The most important criteria of human resources development are population density, literacy, occupation, sex ratio, facilities etc. there for first objective is to study how human resources development is done in Ahmednagar district. This research depends on secondary data, this data collected for Ahmednagra district census during 2011. This data classify in to four grouped in first demography characteristics, occupation pattern, Amentias and Agricultural sectors. In each of these four groups different factors have been taken to calculated level of human development. KEYWORDS: Human resources, amenities, Demographic characteristics, occupation pattern, Amentias, Agricultural, Ranking.
\end{abstract}




\section{INTRODUCTION}

Human resources are one of the most important national resources and base for the study of population geography. The development of any region is needs of human resources development. Indian regional imbalance is one of the problems because low level of human resources development and economical backward region. The regional development needs proper use of human resources developments. The natural resources of the region are affected by the development of the region as well as the human resources of the region. (Gadekar Deepak J 2017) Development is continues process that occupies redeployment and reorientation of the whole economic and social system. The development of any region depends on the resources among them, there is a greater emphasis on human resource. (Mali 1999; Gadekar Deepak J 2015) human resource development depend on the literacy, Population Density, Sex ratio, Population Growth rate, occupation position, Agricultural facilities and Human amenities. (Gadekar Deepak.J., 2016; Gulave S.D. 2020) The most importance reason why the forest area is decaling day by day is increasing population and industrialization and forest is major natural resources. (Gadekar Deepak J 2015). The human beings are a resource, but human beings are subject to huge environmental changes. (Gadekar Deepak J 2020; Kudnar N.S 2015) Human resources are the most important factors contribution to water pollution. (Gadekar Deepak J 2019) woman as resources as well as participation of women is important in any factors. Because of higher the participation of others the higher the family progress. (Gadekar Deepak J 2020) Water pollution major causes of human resources because of human beings have made huge advances in technology at the expenses of their intellect, pollution is increasing in different places. (Bisen, D.K. and Kudnar, N.S. 2013). Water is important role of economic development of any area. Bisen, D.K. and Kudnar N.S. (2019) climate is effected factors for economic development.

\section{STUDY AREA}

The present study Ahmednagar district has been selected as a study area. It extends between $18^{\circ} 20^{\prime}$ and $19^{\circ} 59^{\prime}$ north latitudes and $73^{\circ} 40^{\prime}$ to $75^{\circ} 43^{\prime}$ east longitudes (Map.1) located in part in the upper Godavari basin. The district is very dense in shape and length of $200 \mathrm{~km}$. a width of $210 \mathrm{~km}$. This study region is divided into there are three physical divisions namely, first Sahyadri moutons ranges i.e. Kalsubai, Adula, Baleshwar and Harishchandragad, second Plateau third plains area. The Godavari, Bhima River is the main rivers in this district with the major tributaries are Paravara, Mula, Sina, Dhora, Kukdi ect. And the recharge (water available) of rivers is mainly depending on rainfall in western ghat. Ahmednagar district occupies 17,048 square $\mathrm{km}$ geographical area. The administratively there are divided into 14 tahsils. The average annual rainfalls is $578.8 \mathrm{~mm}$. (22.79") and mean daily maximum temperatures is $39^{\circ} \mathrm{C}$ and mean daily minimum temperature is $11.7^{\circ} \mathrm{C}$. In study region 71.10 percent area under cultivation area out of them 32.40 percent is irrigated and 67.60 percent rain fed or rain shadow area. Its Population is 45, 43,083 (Census 2011) in which male and female are $2,348,802$ and $2,194,281$ correspondingly. The density of population was 266 persons per square kilometers. The economy of the district is chiefly depends on agriculture activities. The variations in climate, soil, drainage, irrigation facility have a predominant influence on agricultural in study area. The cropping pattern is different each irrigated and rain fed areas (Map no 01). 


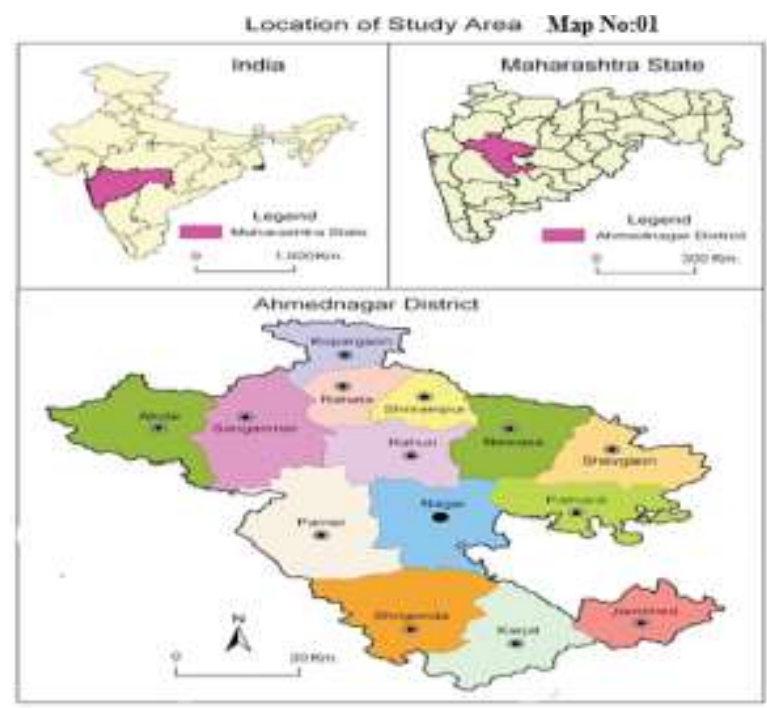

\section{HYPOTHESES}

The hypotheses of this form is taken for this research. The hypothesis is development in Ahmednagar district has been uneven development and effect of Physical, economical factors on development. The based on this hypotheses the researcher is achieving the following objective and used of methodology.

\section{Amis and objective:}

To assess the infrastructural facilities in study area and to examine the level of development in Ahmednagar district at Tehsil level in base of 2011 census year.

\section{METHODOLOGY}

The infrastructural information is collected from census of India 2011 and other government publication and institutional records. In present study human resources, demography, amenities, agricultural and occupation position is taken into consideration. (Gadekar Deepak J 2018) level of human resources development used $\mathrm{Z}$ scoring methods and used 19 parameters in demography, amenities, agricultural and occupation position. (Gadekar Deepak J 2016) temporal human resources development in akole thasil used agricultural, demography, parameters according to and based on 1991 to 2011 census years. Different elements were used to level of human developments. They are sorted accordingly and then take their level and divided it into three level of developments. The level of development are categorized into three parts. In the first one being the most backward, moderate development and last progressive development. Simultaneously the bar graph is used for the cartographic methods and using GIS method for mapping of level of Development.

(Gadekar Deepak Janardhan 2016) the Kendall co-efficient index used for agricultural development in Ahnedngar District as well as he is apply 10 parameters. The used data about below13 variables the co-efficient index is calculated for each tahsil of the study area by using the Kendall's co-efficient index method. The coefficient index is inversely related to development i.e lower the index more development and higher the index low the development. For the calculation of Coefficient index, following formula of Kendall's is used. Kendall's Co - efficient Index $=\frac{\sum \mathbf{R}}{\mathbf{N}}$ Where, $\sum \mathbf{R}=$ Sum of rank , N= Numbers of variable. $X 1=$ Sex ratio; $X 2=$ Literacy rate; $\mathbf{X} \mathbf{3}=$ Population Density; $\mathbf{X} 4=$ Population Growth rate; $\mathbf{X} 5=$ Main workers; $\mathbf{X} \mathbf{6}=\mathrm{HH}$ workers; $\mathbf{X} \mathbf{7}=$ other working population; $\mathbf{X} \mathbf{8}=$ number of telephone; $\mathbf{X} \mathbf{9}=$ Medical facilities; $\mathbf{X 1 0}=$ Education, $\mathbf{X 1 1}=$ Electrification, $\mathbf{X 1 2}=$ Banking, X13= Irrigated area

\section{RESULT AND ANALYSIS}

1. Sex ratio: (Gadekar Deepak J 2018) The sex composition is one of the important demographic elements for the human development. Sex ratio defined as the number of females per thousand males. . Sex ratio is one of the significant indexes of social but also economic condition of an area and important device for regional analysis, of all the demographic attributes of population the sex structure is most essential aspect of humankind. 
2. Literacy rate: (Gadekar Deepak J 2018) Literacy is the very importance indictor for human resources development. Literacy is a valuable tool for social and economic development and general combination. Literacy is one of the significant indicators of status of society in an area. It observed that if the rate of literacy evolution was low thus, economic development slow behind, though the economic development was rapid if the literacy change was fast. The literacy rates in any area were resolute mostly by a collection of historical, social and economic factors.

3. Population Density: (Bisen, Jena DK, et al., 2010; Gadekar Deepak J 2018) Population density is the measurement of land and population resources with the calculation of the ratio between land and population. He should be understanding utilization and optimum considers the availability of resources. The measurement of population distribution and concentration used population density and other parameters, Population density calculated in land man ratio. Calculated population density was ratio between total population and available land.

4. Population Growth rate: (Gadekar Deepak J 2018) Population growth rate good health amenities available with distribution. Population growth rate Low has good economic position in family and well education status. Population growth is spatial temporal change in during or in the years. Population growth is interrelated process in birth, death and migration. It is knowledgeable and the great growth of population and great negative growth of population is unsafe to the socio-economic development of the region. The great growths of population lead to generate the problems of overpopulation whereas the excessive negative growths visibly represent the shortage of resources.

5. Main workers: (Gadekar Deepak J 2018)Those workers who had worked for the major part of the reference period that is six months or more are termed as main workers. The main workers classified into cultivators, labours, peoples engaged in household industry and other workers. The non-workers are classified into people occupied in due home task scholar and student, retired persons, and other non-workers not included and grouped in the main worker's categories.
(Khemnar S. B et al, 2014) in rural area agricultural is the most important activity. (P.H. Mhaske 2011) Land Use \& economic activity change because of increasing population.

6. Main Household workers: (Gadekar Deepak J 2018) The main Household occupations have no profound roots in the region. This category occupation included household industry, manufacturing, processing, servicing and repairs. All these occupations come to the secondary activities. Positive position of human resources development these economical activities.

7. Other main working population: (Gadekar Deepak J 2018) According to census year other main workers means trade and transport economical activities engaged. Other main worker was good indicators for economic and human resources development

8. Number of telephone: (Gadekar Deepak J 2018), The communications have shortest position on human resources development. The communication in the study area observed in post office and, post and telegram office in similar villages. Suppose the laws of distance decompose the distance, beginning such communication facilities center has been calculated factor influence human resources with economic development was negatively

9. Medical facilities: (Gadekar Deepak J 2018) Medical facilities are one of the major concerns in the socio-economic development an area. The medical amenities are vital for human resources development. The availability of medical facilities in the study area have been classified into 05 grouped (Primary Health Centre, Primary Health Sub Centre, Maternity and Child Welfare Centre, Hospital Alternative Medicine, Dispensary)

10. Education: (DK Bisen, NS Kudnar 2013; Gadekar Deepak J 2015) Education is core part in human resources development because of human qualities depends on education status. Therefore, in the study area education facilities classify in five groups one of need full primary sectors, secondary high school, higher secondary junior college, any types senior college with post graduate colleges. The score value was increasing with in increasing education facilities of level.

11. Electrification: (Dabhadker.K.2004) Electrification is the backbone of economic development and any types of works without 
electrification even working is impossible. Electricity is not only used for domestic but commercial, industrial, agricultural sector as a prime factor for maintain the phase the phase of development. Besides economic development the overall human development and the quality of living environment is closely linking with electrification. (Gadekar Deepak J 2018) Electricity use indifferent dimensions thus the level of electrification and consumption plays a vital role in the development process as well as socio economic scenario of rural areas. The main sources of electricity supplier was MESB, all village are electrify. (Kudnar N.S2 018) electricity is importance for agricultural development.

12. Banking: (Gadekar Deepak J 2018) Banking facilities of vital for economic development indicators. In rural economic coeducation and many splay is man sources are banking. This is one of the parameter for human resources development indicators.

13. Irrigated area: (Sonawane V. R 2020) Human resources are the most important factors contribution soil ecosystem has greatly damaged. Because of use chemical and fertilizers in agricultural sectors. Irrigation are the most influential factor for development of agricultural.

(Anil A. Landge (2020) irrigation facilities is depend on the rainfall distribution and amount of rainfall. (Gadekar Deepak J., 2016) Agricultural productivity depends on the environmental factors with Human factors as well as Irrigation facilities, Thus human resources is key factors for agricultural development. (Kudnar N.S. 2015) water is key for development and water Management is key factor for agricultural development. (Kudnar N.S. 2017) It may be supposing that the share of the irrigated area in region directly affected the level of economic development with the agricultural development. ( Kudnar N.S. 2018) Agricultural development conduction effected on the human resources development. (Kudnar N.S. 2019) More share of the irrigated area, higher agricultural area with under crops and development agriculture sectors. (Tupe B.K 2020 and Tupe B.K 2014) Irrigation is affected by agriculture in area here there is high irrigation with agricultural development is high. (Mhaske P.H 2014) irrigation is the factor behind the changing cropping pattern (Rajasekhar, M et.al 2020) and (Kudnar, N.S. \& Rajasekhar, M 2020) water is key role of agricultural development.

\section{Map no 02: Level of Human Resources Development in Ahmednagar District (2011)}

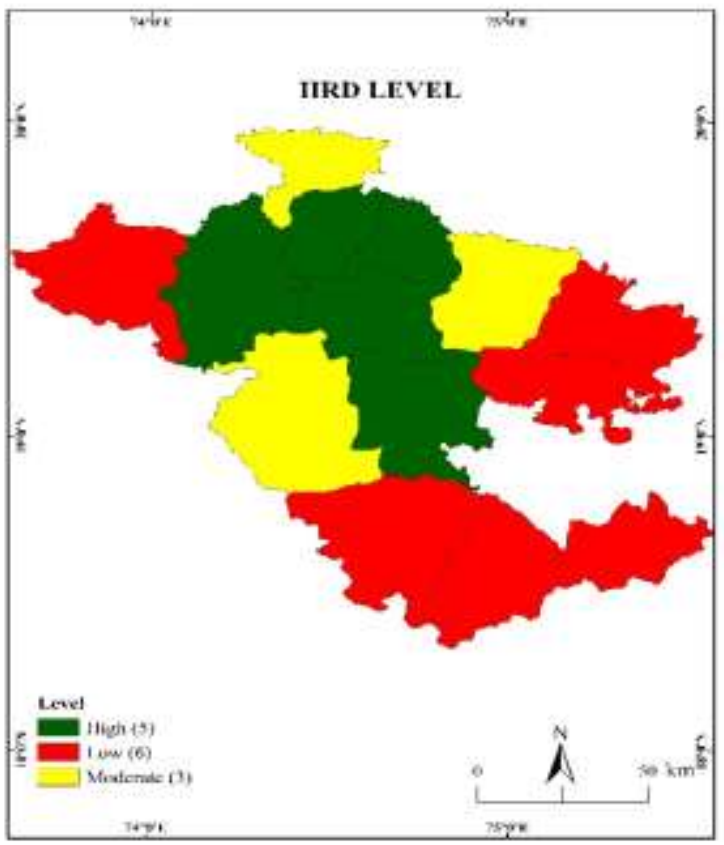


According to the above map it can be stated that the sex ratio is highest in Parner thasil and lowest in Karjat thasil. As well as the literacy rate is highest in Karjet thasil and very poor in Jamkhed thasil and low Akole thasil. Akole, Jamkhed, Karjat, Pathardi, Shevgaon, Shrigonda thses all thasil low development of human because of low status of literacy rate and sex ratio. The literacy is key factors affected on human resources development. Literacy therefore provides the economy status of a home where there is more literacy and in a home that has a low financial position not good literacy status. A total five thasil Nagar, Rahata, Rahuri, Sangamner, Shrirampur are progressive human resources development because of progressive of their thirteen factors. The low and Moderated thasil for HRD effected irrigation facilities. Because of irrigation is affecting the agricultural component in area where the irrigation facility is high. There is more agricultural development as well as in area where there is less irrigation area. The city is not development so that there is a problem of employment. As well as effect of the financial situation is on the factors of the literacy and sex ratio all detail show in map no 01. A human resources development has a total 14 thasil in Ahmednagar district, out of which six thasil are Low Development, those thasil are Akole, Jamkhed, Karjat, Pathardi, Shevgaon, Shrigonda. As well as the three thasil is Moderated Development those thasil is Kopargaon, Nevasa, Parner and lastly Development of HRD were is five thasil, those thasil namely Nagar, Rahata, Rahuri, Sangamner, Shrirampur show detail Graph and Table no 01.

\section{Graph No 01: HRD Level of Ahmednagar District (2011 census)}

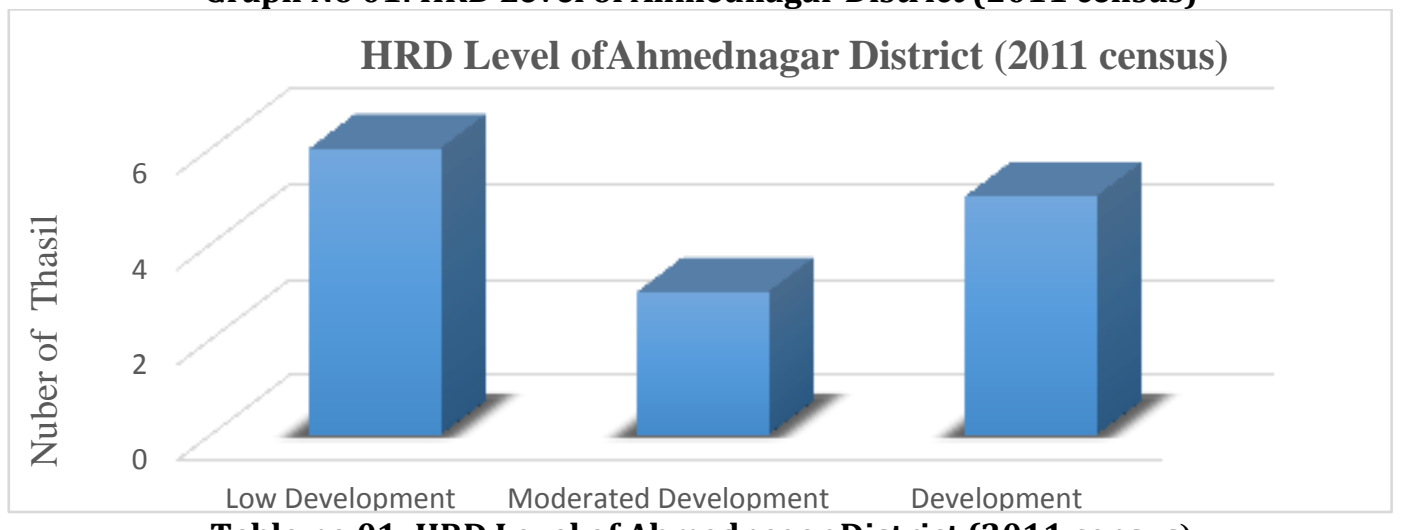

Table no 01: HRD Level of Ahmednagar District (2011 census)

\begin{tabular}{|l|c|c|}
\hline \multicolumn{1}{|c|}{ Level of HRD } & Number of Thasil & Name of Thasil \\
\hline Low Development & 6 & Akole, Jamkhed, Karjat, Pathardi, Shevgaon, Shrigonda \\
\hline Moderated Development & 3 & Kopargaon, Nevasa, Parner \\
\hline Development & 5 & Nagar, Rahata, Rahuri, Sangamner, Shrirampur \\
\hline
\end{tabular}

\section{CONCLUSION}

Natural, economic and social factors effected on human resources development. As well as topography effected on population density, occupation types and pattern with distribution of amenities. Impact of Physical factors on ahmednagar district as well as destruction of human resources parameters. The topography has been affected mainly in the akole thasil as it the western part of the district. (Bisen D.K and Kudnar N.S. 2013) drought prone area effected on economic development. (Bisen D.K and Kudnar N.S. 2013) The population density and low amenities because of effected hilly area. (Bisen D.K and Kudnar N.S. 2013) water is essential for agricultural development. (Anil A Landge et.,al. 2020) the highest rainfall in ahmednagar district falls in the akole thasil and lowest rainfall falls in the Karjat and Jamkhed area. Human resources development has also resulted in uneven development due to uneven distribution rainfall. Irrigation, education is one of the factors influencing development.

Acknowledgement: The author is thankful to the Principal and vice- Principal of Padmashri Vikhe Patil College of Arts, Science \& Commerce, Pravaranagar for providing valuable co-operation and facilities during research work and thanks HOD and My colleague with all PG students.

\section{REFERENCES}

1. Anil A Landge et.,al. (2020)Temporal Variation of Rainfall in Ahmednagar District of Maharashtra, India. Our Heritage,68(30) 12850-12863

2. Bisen D.K and Kudnar N.S. (2013) Watershed development: a case study of drought prone village 
darewadi source, review of research [2249-894x] $d$, pp-1-6.

3. Bisen D.K and Kudnar N.S. (2013) A Sustainable Use and Management of Water Resource of the Wainganga River Basin: - A Traditional Management Systems. figshare. Journal contribution.

4. Bisen D.K and Kudnar N.S. (2013) The production, export and catchment areas market of onion in Indian agriculture, Research Expo International Interdisciplinary Journal, 3(4) 39 -44.

5. Bisen, D.K. and Kudnar N.S. (2019) Climatology, Sai Jyoti Publication, Nagpur, Pp- 1-244.

6. Bisen, Jena DK, et al., (2010) A Geographical Analysis of Population Density Pattern in Bhandara District, The Goa Geographer, 2(1) 130-132.

7. DK Bisen, NS Kudnar (2013) Paradigm shift in the field of Higher Education, Monthly Multidisciplinary Research Journal,2(11) 1-5.

8. Census hand book of India (Ahmednagar District) 1981 and 2011

9. Dabhadker Kaveri \& Dabhadker Megha (2004). Electricity Consumption in Rural Areas- A Case Study of Bilaspur Region, Chhattisgarh State. The Deccan Geographer, Pune, Volume42 Number2P/p35-41.

10. Gadekar Deepak J (2015) A Statistical Analysis of Foreign and Domestic Tourist in India, Scholars World - International Refereed Multidisciplinary Journal of Contemporary Research, (3) 78-84.

11. Gadekar Deepak J (2015) Human Resources Development in the Akole Tahsil, Ahemdnagar District (M.S,India), Quest International Multidisciplinary Research Journal 4(4) 113-119.

12. Gadekar Deepak J (2015) Level of Human Resources Development- Concepts and Review, Acme international Journal of Multidisciplinary Research, 3(6) 48-61.

13. Gadekar Deepak J (2017) Regional Disparities of Socio- Economic Development in Ahmednagar District, Maharashtra (India) , International Journal of Recent Research and Applied Studies 4 (5), 30-36

14. Gadekar Deepak J (2018)Level of Human Resources Development in the Akole Tahsil DistrictAhmednagra Maharashtra unpublished Ph.D Thesis Savitribai Phule Pune University

15. Gadekar Deepak J (2019) Regional Disparities of Woman Resources in the AkoleTahsil District Ahemdnagr Maharashtra State, India. Online International Interdisciplinary Research Journal, 9(2), 94-99.

16. Gadekar Deepak Janardhan (2016) A Hybrid Land Cover Classification of Landsat-7 \& 8 (OLI) ETM+ Data for Resourceful Vegetation Mapping - Akole Thasil Dist- Ahmednagar, M.S, India, American International Journal of Research in Humanities Arts and Social Sciences,13(3) 217-221.

17. Gadekar Deepak Janardhan (2016) A Temporal Study of Human Resources Development in the
Akole Tahasil, International Journal of Research, 3(5) 273-280.

18. Gadekar Deepak Janardhan (2016) Regional Disparities of Agricultural Development in Ahmednagar District, MS, India, International Journal of Research in Social Sciences, 6(8), 389403.

19. Gadekar Deepak Janardhan (2020) A Study of Chemical Characteristic of Pravara River, In Different Sites-Ahmednagar District, Maharastra, India. Our Heritage 68(1) 4977-4988.

20. Khemnar Shivaji Bhagwan et.al, (2014) Development of Land Utilizes: Summarize in Akole Tahsil (Ahmednagar District), MS, India. International Journal of Science and Research, 3(12) 1506-1509.

21. Kudnar N. S., (2018): Water Pollution a Major Issue in Urban Areas: A Case Study of the Wainganga River Basin". Vidyawarta International Multidisciplinary Research Journal, pp 78-84.

22. Kudnar, N. S., (2015) "Linear Aspects of The Wainganga River Basin Morphometry Using Geographical Information System”. Monthly Multidisciplinary Online Research Journal Review of Research, pp 1-9.

23. Kudnar N. S., (2019): Impacts Of GPS-Based Mobile Application For Tourism: A Case Study Of Gondia District, Vidhyawarta, Peer-Reviewed International Publication, PP-19-22.

24. Kudnar, N. S., (2017): Morphometric Analysis of the Wainganga River Basin Using Traditional \& GIS Techniques, Ph.D. Thesis, Rashtrasant Tukadoji Maharaj Nagpur University, Nagpur, Pp 66-250.

25. Kudnar, N. S., (2015) Linear Aspects of the Wainganga River Basin Morphometry Using Geographical Information System”. Monthly Multidisciplinary Online Research Journal Review of Research, pp 1-9.

26. Kudnar N.S (2018) Agriculture Development And Management Plan: A Case Study Of The Wainganga River Basin", International Journal of Multifaceted and Multilingual Studies Research Journal

27. Kudnar, N.S. \& Rajasekhar, M (2020) A study of the morphometric analysis and cycle of erosion in Waingangā Basin, India, Modeling Earth Systems and Environment 6 (1), 311-327 https://doi.org/10.1007/s40808-019-00680-1

28. Mali K.A (1999), Level of Human resources development in Amravati district. A special perspective published in Maharashtra Bhugolshatra Sanshodhan Patrika, Pune. Vol. XIII No 02. 153161.

29. Mhaske P.H and Tupe B.K (2014) Demands of Changes in Cropping Pattern: A Case Study of Akole Tahasil (M.S, India)', International Journal of Science and Research, 3(5) 1314- 19.

30. Musmade Arjun H, Saptarshi Praveen G, More Jyotiram C. (2012), The study of Human Resources 
Development in the RahuriTahsil of Ahmadnagar District (Maharashtra) Maharashtra Bhugolshatra Sanshodhan Patrika, Vol. XXIX No 01, 9-12

31. P.H. Mhaske (2011) Land Use \& Economic Activity in Shirdi Rahata Taluka, District Ahemadnagar M.H, International Referred Research Journal, Research analysis and Evaluation, 2 (18) 75-76. https://www.researchgate.net/publication/33941144 9

32. Pandey Deepika, Singh and Rai (2010). Human Resources Development in Varanasi District: A Geographical Analysis. Uttar Pradesh Geographical Journal Kanpur Volume 15, 32 - 41

33. Rajasekhar, M., Gadhiraju, S.R., Kadam, A. et al. (2020) Identification of groundwater rechargebased potential rainwater harvesting sites for sustainable development of a semiarid region of southern India using geospatial, AHP, and SCS-CN approach. Arab J Geosci, pp 13-24.

34. S.D Gulave (2020) Use of Landsat ETM+ Data for Delineation of Vegetation Cover Area in Akole Thasil, , International Research Journal of Engineering and Technology, Volume 7, (2)57-61.

35. Sonawane Vijay R. et.,al. (2020) Analysis of Chemical Properties of Soil under Sugarcane Crop: A Case Study of Khandala, Shrirampur, Ahmednagar District, Maharashtra State, India. Our Heritage 68(30), 6522-6547.

36. Sonawane Vijay R. et.,al.(2020) Geographical Study of Crop Combination in Tribal Area of Nashik District, Maharashtra, India. Studies in Indian Place Names, 40(3)3915-3940.

37. Tupe B.K (2014) Demands of Changes in Cropping Pattern: A Case Study of Akole Tahsil', International Journal of Science and Research, 3(5)

38. Tupe B.K (2020) A Geographical Study of Nilwande Canal in Ahmednagar District, Pravara River, M.S, India. International Research Journal of Engineering and Technology, 7(2) 2214-2219. 